\title{
LESSON LEARN DI SMA NEGERI 5 KEDIRI PADA MATAPELAJARAN BIOLOGI MATERI STRUKRUR DAN FUNGSI SEL PENYUSUSN JARINGAN HEWAN
}

\author{
Mumun Nurmilawati ${ }^{1}$ dan Siti Fatimah ${ }^{2}$ \\ ${ }^{1}$ Dosen Program Studi Pendidikan BiologiUniversitas Nusantara PGRI Kediri \\ ${ }^{2}$ Guru Mata Pelajaran Biologi SMA Negeri 5 Kediri \\ Email: mumunnurmila68@gmail.com
}

\begin{abstract}
ABSTRAK
Penelitian ini bertujuan untuk mengetahui praktik terbaik, kendala, dan upayadalam proses pembelajaran di SMA Negeri 5 Kediri pada materi struktur dan fungsi sel penyusun jaringan hewan. Metode yang digunakan dalam penelitian ini adalah deskriptif kualitatif. Hasil yang diperoleh untuk pembelajaran struktur dan fungsi sel penyusun jaringan hewan dengan menggunakan metode diskusi dan eksperimen, kendala yang ditemukan proses pembelajaran di SMA Negeri 5 Kediri yaitu dalam proses pembelajaran jika menggunakan metode yang sama dalam beberapa kali pertemuan menyebabkan kebosanan pada siswa, siswa cenderung tidak mau membaca baik modul maupun buku pegangan yang telah dimiliki, dan alokasi waktu yang tidak sesuai. Sedangkan upaya yang dilakukan adalah menggunakan metode yang bervariasi dalam proses pembelajaran, meminta siswa untuk membaca sumber sebelum memulai pembelajaran.
\end{abstract}

Kata kunci: Lesson Learn, Biologi.

\section{PENDAHULUAN}

Mata pelajaran biologi adalah salah satu mata pelajaran yang wajib ditempuh oleh siswa SMA terutama yang mengambil jurusan MIPA. Dalam satu minggu untuk mata pelajaran biologi di kelas XI waktunya 4 jam pelajaran atau 2 kali pertemuan. Materi yang terdapat di kelas XI salah satunya adalah Struktur dan Fungsi Sel Penyususn Jaringan Hewan. Materi tentang struktur dan fungsi sel penyusun jaringan hewan sangat sulit dipahami karena bersifat abstrak, hal ini dibenarkan oleh guru mata pelajaran biologi yang ada di SMA Negeri 5 Kediri karena sering kali siswa tidak bisa melihat secara nyata karena objeknya mikroskopis dan hanya berdasarkan gambar-gambar saja. Hal ini sesuai dengan pendapat [1] yang menyatakan bahwa objek-objek biologi yang bersifat mikroskopis sulit dipahami oleh siswa.

Oleh karena dibutuhkan metode agar pembelajaran materi struktur dan fungsi sel penyusun jaringan hewan lebih mudah dipahami olehsiswa. Berdasarkan hasil wawancara dengan guru biologi, menyatakan bahwa siswa yang sekarang duduk di kelas XI belum pernah melakukan pengamatan dengan menggunakan mikroskop. Untuk itu perlu latihan dalam penggunaan mikroskop, karena banyak materi biologi yang harus diamati dengan menggunakan mikroskop. Selain itu siswa kurang aktif saat dilakukan pembelajaran dengan menggunakan metode ceramah.

Dari hasil wawancara tersebut maka dipilih metode pembelajaran diskusi dan praktikum untuk meningkatkan pemahaman siswa dan aktifitas belajar. Menurut Djamarah dan Zain [2], metode diskusi merupakan metode yang menghadapkan siswa pada suatu pernyataan atau pertanyaan yang bersifat problematika untuk dipecahkan. Sedangkan metode eksperimen merupakan metode yang menghadapkan siswa agar mengalami dan membuktikan sendiri materi yang dipelajari [3].

\section{METODE PENELITIAN}

Metode penelitian yang digunakan adalah metode deskriptif kualitatif. Data yang diperoleh data yang terkait dalam proses pembelajaran selama empat kali pertemuan. Untuk memperoleh kebenaran data maka peneliti melakukan pengecekan temuannya dengan jalan membandingkan dengan berbagai sumber dan teori.

Lesson Learn di...

Nurmilawati dan Fatimah 


\section{HASIL DAN PEMBAHASAN}

Pertemuan pertama (dilaksanakan pada senintanggal 3 September 2018)

Sesuai dengan metode pembelajaran yang digunakan yaitu metode diskusi langkah pertama yang dilakukan adalah memberikan motivasi dan apersepsi dengan meminta siswa untuk melakukan gerakan menggosok-gosok kulit tangan. Kemudian peneliti memberikan pertanyaan "apa yang dihasilkan dari menggosok-gosok kulit?" Jawaban para siswa adalah kotoron yang menempel pada kulit. Di apersepsi ini peneliti mulai memperkenalkan tentang sturktur dan sel penyusun jaringan hewan.

Langkahkedua adalah dengan memberikan Lembar Diskusi Siswa/LDS (dengan sub materi jaringan epitelium) dan meminta mereka untuk mengerjakan dengan membaca sumber belajar baik dari modul, buku pegangan siswa maupun dari internet secara berkelompok.

Dari hasil pengamatan selama berdiskusi menunjukkan bahwa siswa kesulitan untuk mengidentifikasi gambar yang ada dalam LDS. Hal ini disebabkan karena siswa tidak membaca secara detail apa yang ada dalam sumber belajar yaitu modul dan buku pegangan siswa. Siswa cenderung untuk melihat gambar tanpa mencari ciri-ciri dari masing-masing gambar tersebut.

Karena keterbatasan waktu maka pertemuan pertama belum bisa tuntas dalam mengerjakan LDS, namun siswa sudah berani untuk tampil presentasi di depankelas.

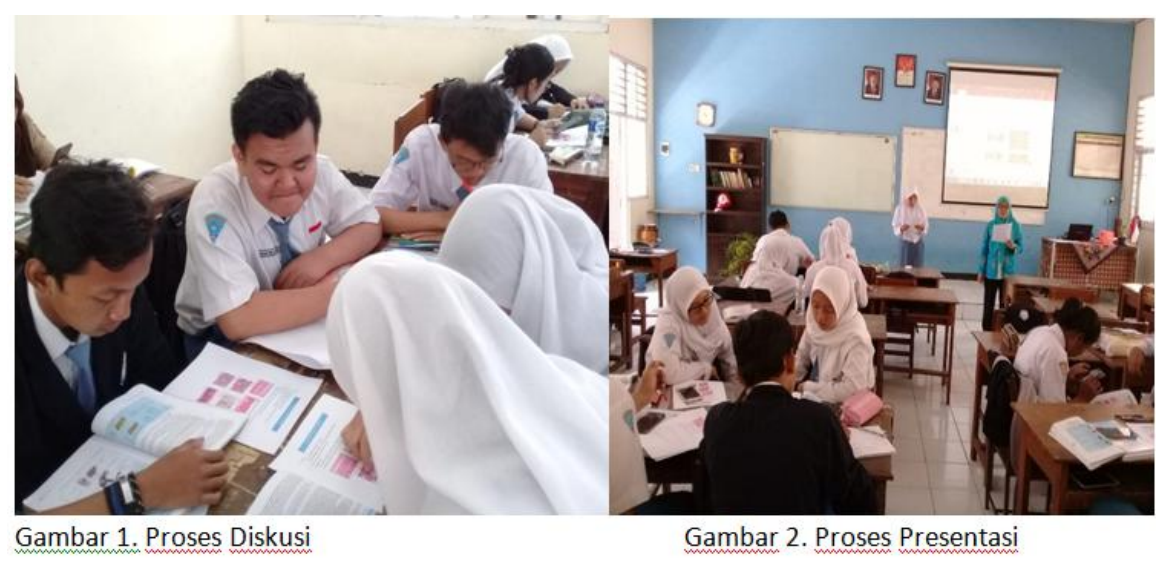

Pertemuan Kedua (pelaksanaan hari Selasa tanggal 4 September 2018)

Proses pembelajaran pada pertemuan kedua melanjutkan pembahasan materi pada pertemuan pertama yang belum tuntas. Dari hasil presentasi masing-masing kelompok tampak bahwa siswa sangat mencermati apa yang disampaikan oleh kelompok lain, hal ini terlihat saat ada kelompok yang salah dalam membahas materi maka kelompok yang lain akan merespon dengan mennyampaikan pendapatnya. Hal ini menunjukkan bahwa diskusi sangat berjalan dengan baik.

Setelah menyelesaikan materi pada LDS kesatu dilanjutkan dengan mengerjakan LDS yang kedua. Langkah-langkah yang dilakukan pada pertemuan kedua masih sama dengan menggunakan metode pembelajaran diskusi. Pada pertemuan kedua sudah mengalami kemajuan ditunjukkan dengan siswa mampu menjawab pertanyaan pada LDS kedua meskipun belum tuntas semua presentasinya.

\section{Pertemuan Ketiga (pelaksanaan hari Senin tanggal 10 September 2018)}

Pada pertemuan ketiga situasi pembelajaran lebih kondusif dengan bukti siswa sangat antusias saat peneliti menanyakan tentang "dimana terdapat tulang rawan?" sebagian besar siswa menjawab ada di telinga dan ujung hidung sambil memegangi telinga dan hidung. Siswa bisa menjawab demikian karena bisa merasakan sendiri bagian tersebut. Saat ditanya "mengapa tubuh bisa membungkuk?" jawaban siswa karena ada persendian. Jawaban ini menunjukkan bahwa siswa belum mengetahui diantara tulang rusu kterdapat tulang rawan. Ini berarti bahwa siswa membutuhkan contoh konkrit dalam mempelajari materi tentang jaringan. Dari hasil pengamatan 
peneliti menunjukkan bahwa siswa mulai bosan dengan strategi yang digunakan, sehingga pada pertemuan keempat dilakukan strategi yang berbedadenganpertemuan satu sampai ketiga.

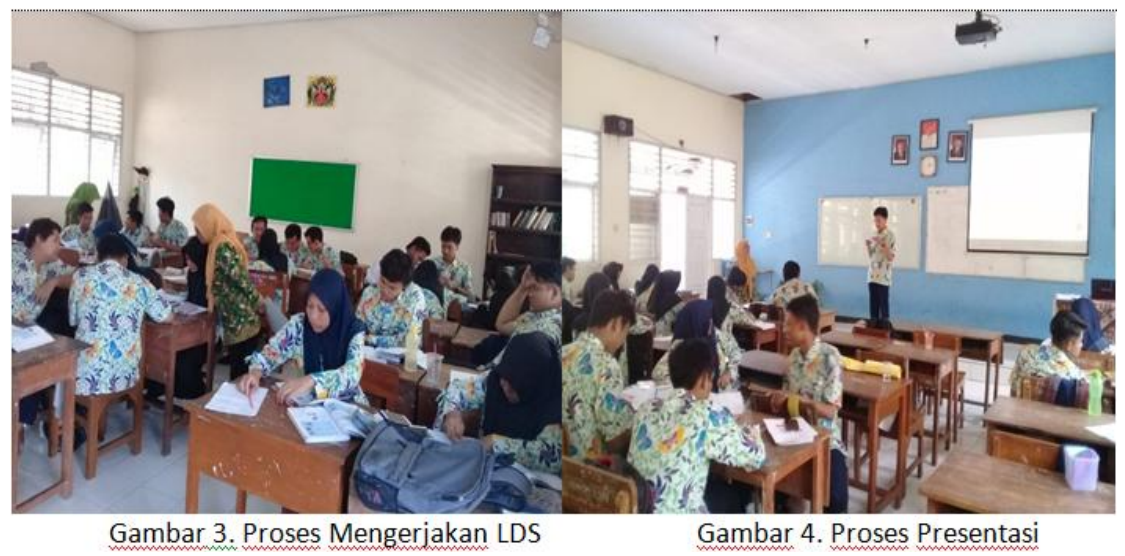

Di akhir pembelajaran pertemuan ketiga siswa diminta untuk menyiapkan diri dalam pertemuan keempat yang akan dilaksanakan di laboratorium dengan melakukan pengamatan preparat awetan struktur jaringan hewan.

Pertemuan keempat (pelaksanaan hari Senin tanggal 17 September 2018)

Sesuai dengan RPP yang telah dibuat maka pertemuan keempat proses pembelajaran dilakukan di laboratorium biologi dengan melakukan pengamatan preparat awetan struktur jaringan hewan. Di awal pembelajaran, peneliti memberikan petunjuk bagaimana cara menggunakan mikroskop mengingat seperti yang sudah disampaikan oleh guru mata pelajaran biologi bahwa siswa belum pernah menggunakan mikroskop, meskipun ada beberapa siswa yang pernah menggunakan saat di SMP.

Siswa sangat antusias saat mereka melakukan proses pembelajaran, ada pengalaman baru yang didapatkan oleh mereka yaitu dapat dengan nyata melihat jaringan hewan yang sebelumnya dirasa abstrak. Meskipun siswa sudah bisa mengamati tentang struktur jarinngan hewan namun masih belum mampu mengidentifikasi jaringan dengan tepat, karena siswa berasumsi bahwa jaringan yang telah dipelajari bisa terlihat secara sendiri-sendiri. Sehingga hasil pengamatan yang didapatkan masih perlu untuk diperjelas dengan menunjukkan bagian dari masing-masing jaringan. Hasil pengamatan kemudian dipresentasikan.

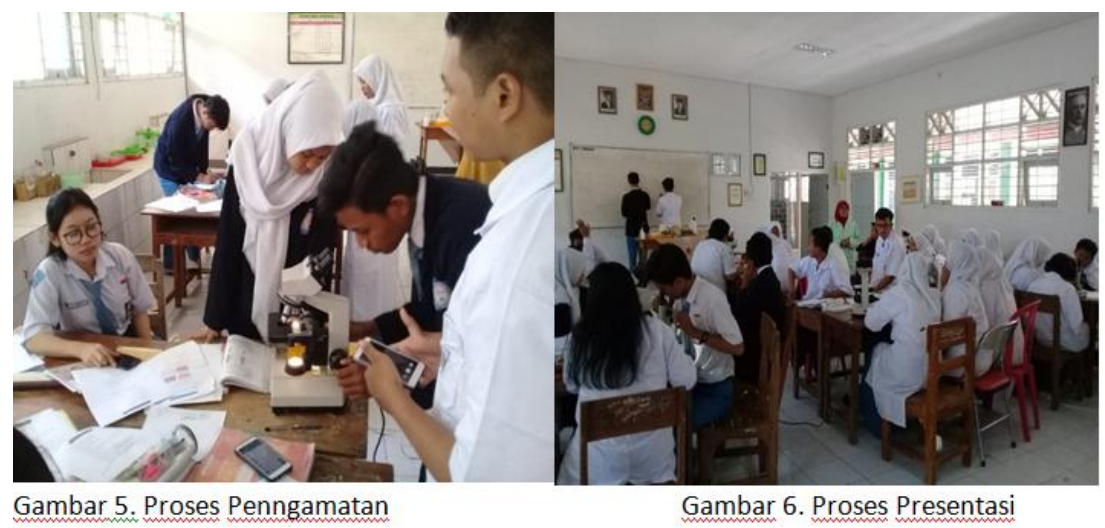

Pada pertemuan pertama adabe berapa kendala yang dihadapi oleh peneliti yaitu perlunya adaptasi peneliti dengan situasi kelas yang baru demikian juga dengan siswa. Saat digunakan metode diskusi, siswa terkesan masih merasa canggung untuk melakukan diskusi dengan temannya. Hal ini tampak ketika siswa diminta untuk segera berdiskusi dengan kelompoknya mereka enggan untuk pindah tempat duduknya. Namun setelah peneliti menegaskan untuk segera berkumpul dengan

Lesson Learn di...

Nurmilawati dan Fatimah 
kelompoknya dan menentukan tempat duduk masing-masing kelompok, mereka segera menuju tempat duduknya.

Hal ini berbeda dengan pertemuan kedua, ketiga dan keempat, mereka dengan senang hati berkelompok sesuai dengant empat duduknya. Kendala yang dihadapi pada pertemuan kedua adalah siswa kurang membaca sumber belajar yang ada. Seharusnya siswa sudah membaca buku sumber belajar yang telah dimiliki untuk menguasai materi. Menurut Majid [4] untuk menguasai kompetensi secara runtut dan sistematis dibutuhkan bahan ajar.

Selain sumber belajar, kendala yang dihadapi oleh peneliti adalah alokasi waktu. Proses pembelajaran dilakukan pada hari Senin dan Selasa. Alokasi pada hari Senin seringkali terpotong untuk kegiatan upacara sehingga waktu yang seharusnya bisa digunakan untuk menyelesaikan materi akhirnya tidak bisa terselesaikan. Menurut Fajar [1] alokasi waktu pembelajaran direncanakan secara rinci agar memudahkan guru dalam melaksanakan pembelajaran.

Salah satu keberhasilan dalam pembelajaran adalah metode yang digunakan oleh guru, dalam proses pembalajaran dengan materi struktur dan fungsi sel penyusun jaringan hewan metode yang digunakan adalah diskusi dan eksperimen. Metode diskusi digunakan agar siswalebih aktif demikian juga dengan metode eksperimen. Kelebihan dari metode diskusi adalah 1) memotivasi kraetivitas siswa untuk mendapatkan ide dan gagasan untuk memecahkan masalah, 2) sikap menghargai/sosial akan terbentuk, 3) mengembangkan sikap bahwa memecahkan masalah bersama lebih baik, 4) dengan melakukan diskusi mendapatkan beberapa solusi dalam memecahkan masalah [2][5][6]. Dari hasil peneleitian menujukkan bahwa keaktifan siswa meningkat ditandai dengan semakin banyaknya siswa yang berani dalam mempresentasikan hasil diskusi. Sependapat dengan Prianto [7] yang menyatakan dengan menggunakan metode diskusi aktifitas siswa semakin meningkat.

Kelebihan metode eksperimen antara lain 1) dengan melakukan percobaan siswa merasa lebih percaya diri dengan kebenaran kesimpulan yang didapatkannya, 2) penemuan yang didapatkan oleh siswa merupakan terobosan baru yang dapat memecahkan masalah, 3) hasil percobaan dapat digunakan untuk kepentingan masyarakat. Hal ini ditunjukkan dengan siswa merasa senang dengan hasil yang didapatkan melalui metode eksperimen meskipun gambar yang didapatkan dengan mengamati preparat belum tepat secara keseluruhan. Senada dengan Andiasari [8] yang menyatakan bahwa senang belajar IPA dengan menggunakan metode eksperimen.

\section{KESIMPULAN}

Dari penelitian yang telah dilakukan didapatkan kesimpulan bahwa dalam proses pembelajaran di kelas XI MIPA 4, materi struktur dan fungsi sel penyusun jaringan hewan dengan menggunkan metode diskusi dan eksperimen merupakan praktik terbaik. Kendala yang dihadapi oleh peneliti adalah siswa cenderung tidak mau membaca baik modul maupun buku pegangan yang telah dimiliki, dan alokasi waktu yang tidak sesuai, sedangkan upaya yang dilakukan adalah meminta siswa untuk membaca sumber sebelum memulai pembelajaran dan manajemen waktu perludilakukan agar pembelajaran sesuai denngan rencana.

\section{DAFTAR PUSTAKA}

[1]. Fajar, NI. 2016. Proses Pembelajaran Biologi Pada Materi Sistem Peredaran Darah Manusia Di Kelas VIII SMP Negeri 3 Rambatan. Jurnal Ta'dib. Vol 19. No. 2. Desember 2016.

[2]. Djamarah, S. B. i dan Z, A. 1996. Strategi Belajar Mengajar. Jakarta: Rineka Cipta.

[3]. Sagala, S. (2006). Konsep dan Makna Pembelajaran. Bandung: Alfabeta.

[4]. Majid, A. 2006. Perencanaan Pembelajaran. Bandung: Remaja Rosdakarya.

[5]. Subiyanto. 1990. Strategi Belajar Mengajar IPA. Malang: IKIP Malang

[6]. Lufri. 2007. Kurikulum dan Pembelajaran.Jakarta: BumiAksara

[7]. Prianto, P. T. 2017. Metode Diskusi Macromedia Flash Untuk Peningkatan Hasil Belajar Alat Ukur Mekanik. Jurnal Vokasi. Vol. 5. No. 1. Juni 2017. 
Jurnal Biologi dan Pembelajarannya, Vol 6 No 1, April 2019. Pp: 18-22

e-ISSN: $2406-8659$

[8]. Andisari, L. 2015. Penggunaan Model Inquiry dengan Metode Eksperimen dalam Pembelajaran IPA di SMPN 10 Probolinggo. Jurnal Kebijakan dan Pengembangan Pendidikan. Vol 3. No. 1, Januari 2015. 15-20 ISSN:2337-7623; EISSN: 2337-7615. 